A keen Territorial from the founding of the force in 1908, he carried on the eye departments of the East Leeds' and Beckett Park Military Hospitals from 1914-1918, being presented to His Late Majesty King George $V$ at each of the Royal visits.

$\mathrm{He}$ was instrumental in persuading the authorities during this period to accept large numbers of men who had been rejected for defects that would be considered trifling in soldiers today.

Appointed Consulting Surgeon in 1919, he retired to the south, but kept up his professional activities, as a member of the Committee of the Bath Eye Infirmary, Pensions Secretary of the Wiltshire Association of the Blind, and as moving spirit and Chairman until 1939 of the Foundation Committee of the Bradford-on-Avon District Hospital.

His last public appearance was at the-opening of this Hospital in September, 1947.

His manual dexterity both as an operator and as an amateur carpenter is a lively memory to such few of his colleagues as remain with us.

A more permanent memorial will be his influence on the design of the new Leeds Infirmary buildings, where his architectural ingenuity and untiring work are remembered with gratitude.

His publications include:-

Sarcoma of Iris. Trans. Ophthal. Soc., U.K. Vol. XV, p. 814. 1895.

Cysticercus of conjunctiva. ibid. Vol. XVI, p. 47. 1896.'

Tumour of optic nerve. ibid. p. 139. 1896.

A diagrammatic model intended to assist in the teaching of ocular refraction. ibid. Vol. XXI, p. 142. 1901.

A model to illustrate the passage of rays of light through the eye in the various forms of astigmatism. ibid. Vol. XXV, p. 307. 1905.

Dr Luckhoff of Cape Town, writes:-

"..... How clearly I can visualise him, his springy alertness, his quickness of mind, his cheerful smile, and the quiet efficiency, equanimity, precision, and finish of everything he undertook.

His handwriting to the last showed the neatness, exactness, and good discipline of an orderly mind.

His complete integrity and openness of character was as refreshing as the nature he loved so well. I have no doubt that he was belovéd and admired by all who knew him."

\title{
JOHN ROWAN
}

JoHn Rowan died at his home near Prestwick on March 17. A native of Greenock, he retained his love and affection for the West of Scotland throughout his long life. He graduated M.B., C.M., in 


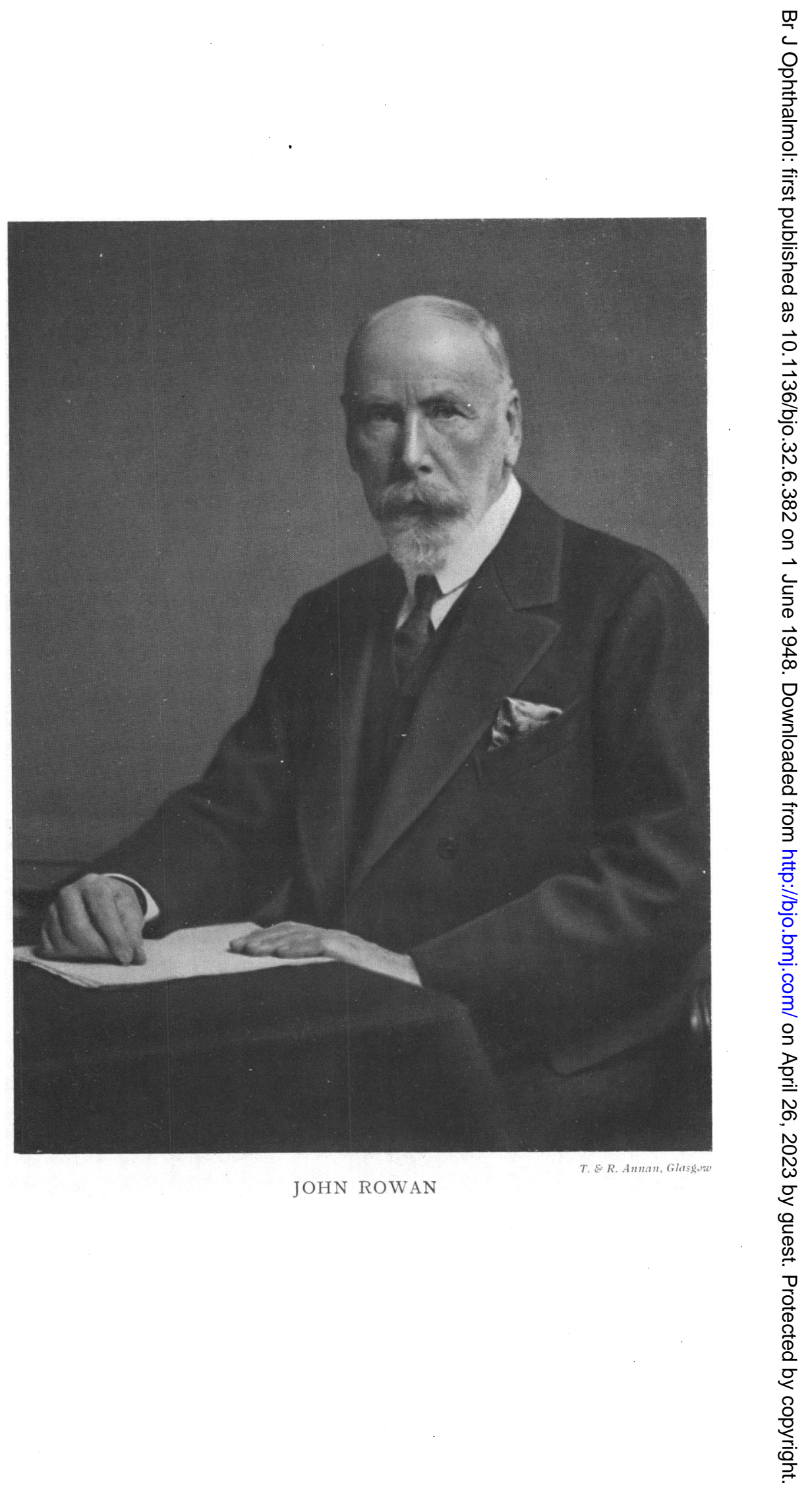


the University of Glasgow in 1889, and received his early training in resident appointments in the Greenock Royal Infirmary. He was subsequently a clinical assistant at Moorfields and the Royal Westminster Ophthalmic Hospital. During these formative years, he made friendships which he retained steadfastly, and in his latter years he recalled with a quiet gusto the clinical incidents which had influenced his receptive mind. He made study visits to Berlin, Göttingen, $\overrightarrow{\mathrm{P}}$ aris and Dublin, and returned to Glasgow in the early nineties. At that period, F. H. Napier, who now lives in retirement in Johannesburg, succeeded the celebrated J. R. Wolfe, known to several generations of medical students in relation to his method of skin grafting. , Rowan became Assistant Surgeon to the Ophthalmic Institution, which had been founded by Wolfe in 1868, and retained this association throughout his life, being promoted Surgeon in 1916 and Honorary Consulting Surgeon in 1924,

He became a Member of the Ophthalmological Society of the United Kingdom in 1893, and was an original member of the Oxford Ophthalmological Congress. He was one of the pioneers of the ophthalmic examination of school children, and data from one of his early papers on the distribution of refractive errors in childhood were incorporated by Karl Pearson in his monograph on the inheritance of vision. Writing did not come easily to him, but he made several contributions to the proceedings of the various clinical and scientific bodies of which he was a member, and his remarks at meetings were frequently pawky and characteristic. In 1900 Rowan was elected a Fellow of the Royal Faculty of Physicians: and Surgeons, and served on the board of management of the Glasgow Royal Mental Hospital and the Glasgow Veterinary College. At the meeting of the British Medical Association in 1922, he was vice-president of the Section of Ophthalmology.

He had a love for the country, and devoted much thought and care to the entertainment of his friends on a fishing or shooting expedition. About ten years ago, he retired from active practice, as he found that his progressive deafness was putting too great a strain upon his patients. Both his hospital and private work were carried out with meticulous attention to detail, and in the finest tradition of the great, men whom he knew, well in the old Moorfields. His manner could be aloof and distant, but once his confidence was gained, the discovery would be made that he was both shy and unassuming. He was for a long time associated with the Royal Sick Children's Hospital, and many old patients can recall his gentleness to them as children.

The present generation of ophthalmologists saw very little of him, and to some he represented the last of the Victorians. Ceremonial and formal they may have been, but we have lost the integration of 
outlook and singleness of purpose which were strongly developed in John Rowan. He was a bachelor, and in the later years he would recall his old friends and teachers; for Nettleship and Treacher Collins he had unbounded admiration. He kept in touch by correspondence with old patients, friends and colleagues up to the end, and his interest in the progress of his chosen specialty did not fail.

\section{NOTES}

Honour

Sir Stewart DUKe-Elder, K.C.V.O., and Mrs. Philippa P. Martin have been elected fellows of University College, London.

Pan-American

Association of

Ophthalmology
Dr. ConRaD Berens has been elected President of the Pan-American Association of Ophthalmology. The next Congress is to be held in Mexico City in 1952. Twelve vice-presidents have also been elected. Dr. M. E. Akaro was re-elected Secretary for Countries south of the Isthmus, and Dr. T. D. Allen succeeds Dr. Berens as Secretary for Countries North of the Isthmus of Panama. The Congress held in Havana in January of this year adopted statutes and by-laws, and permanent committees have been set up to deal with encouragement of research, glaucoma, trachoma, lighting and optics, contact lenses, orthoptics, prevention of blindness, neuro-ophthalmology, legal and industrial ophthalmology and other subjects. 